Contents List available at RAZI Publishing

Journal CleanWAS

Journal Homepage: http://www.razipublishing.com/journals/journal-cleanwas/

https://doi.org/10.26480/jcleanwas.01.2017.30.34

\title{
ASSESSING WATER CONSUMPTION OF BARLEY CULTIVATION IN THI-QAR PROVINCE, IRAQ
}

\author{
Mahmood Jamal AbdulHasan1, Marlia M. Hanafiah1, ${ }^{*}$ \\ 1School of Environmental and Natural Resource Sciences, Faculty of Science and Technology, Universiti Kebangsaan Malaysia, 43600 Bangi, \\ Selangor, Malaysia \\ *Corresponding author: mhmarlia@ukm.edu.my
}

This is an open access article distributed under the Creative Commons Attribution License, which permits unrestricted use, distribution, and reproduction in any medium, provided the original work is properly cited

\section{ARTICLE DETAILS}

Article history:

Received 27 September 2016

Accepted 13 December 2016

Available online 10 January 2017

Keywords:

Water footprint, Water scarcity, Water consumption, Crop production, Iraq

\begin{abstract}
We assessed the blue and green water consumption for cultivating barley in the Thi-Qar province, Iraq. CROPWAT 8.0 model was used to compute the total crop water use for both crops based on the meteorological data such as rainfall, maximum and minimum temperature, wind speed, sunshine and humidity as well as the soil and crop characteristics. The Penmann-Monteith method has been applied to calculate the evapotranspiration rate. The results showed that the ranges of blue water consumption for barley for10 years were between $761 \mathrm{~m} 3 /$ ton $2,275 \mathrm{~m} 3 /$ ton. Whereas the green water footprint for the same years was ranged from $47 \mathrm{~m} 3 / \mathrm{ton}-1,235 \mathrm{~m} 3 /$ ton. The results of this study can provide valuable information about water consumption and water availability in the Thi-Qar Province and serve as a guideline to solve or reduce water scarcity problem, thus help the relevant authorities to adopt new water strategies for Thi-Qar Province, Iraq.
\end{abstract}

\section{INTRODUCTION}

Freshwater has always been a life-essential resource to human beings and important for the agriculture sector to irrigate and supply water for crops cultivation. However, international law concerning cross-national freshwater resources is poorly developed, viewed as contradictory and often unenforceable [16]. Unlike any other commodity (such as oil), there is no substitute to water [15]. The increasing water scarcity due to rising water demands and a changing climate is seen as a main issue for many countries. Cooperation and initiative from various relevant agencies such as government, private sector and public are urgently needed to achieve sustainable water management [9]. At the same time, several indicators suggest that water scarcity will become an even worse in the future. In addition, access to water will be reduced because of increased demands (population growth and industrialization), reduced water quality (resulting from pollution) as well as uneven distribution of the resource and climate change [12]. Climate change, water pollution, high water demand and overuse of water are the main causes lead to water shortage. While water crisis is defined when there is not enough clean potable water for a given population. Two mechanisms are involved in water scarcity, i.e. physical water scarcity and economic water scarcity. Physical water scarcity occurs when natural water resources are inadequate to supply a region's demand, while economic water scarcity is when the sufficient available water resources are poorly managed.

The largest consumer of water across the region is from the agriculture sector where it accounts for more than $70 \%$ of water demand [8]. Therefore, the water shortage issue cannot be addressed without a detailed consideration of agriculture sector [17]. Water scarcity is one of the serious problems facing the Arab region. Iraq comes first on the list of countries that suffer from this problem for many reasons [1]. It is about time to assess the sustainability of freshwater consumption by agriculture sector using a water footprint approach. The water footprint is an indicator of freshwater use that looks at both direct and indirect water use of a consumer or producer. Water use is measured in terms of water volumes consumed (evaporated or incorporated into a product) and/or polluted per unit of time. The water footprint is a geographically explicit indicator, showing not only volumes of water use and pollution, but also the locations [2]. Water footprint used to show the location or area where water needs to be available for products and services [5].

\section{$2.1 \quad$ Study Area}

Thi-Qar Province covers an area of $13,552 \mathrm{~km} 2$ with an estimated population of 1,450,200 people and located in the Southern Iraq to the North of Basrah Governorate and shares internal boundaries with the Provinces of Missan, Muthanna, Qadissiya and Wassit (Figure 1). It is about $370 \mathrm{~km}$ southeast of Baghdad between $31^{\circ} 14 \mathrm{~N}-46^{\circ} 19 \mathrm{E}$. The capital city of this province is Nasiriyah. Thi-Qar Province is characterized by long hot summer and short winter with low rate of rainfall throughout a year.

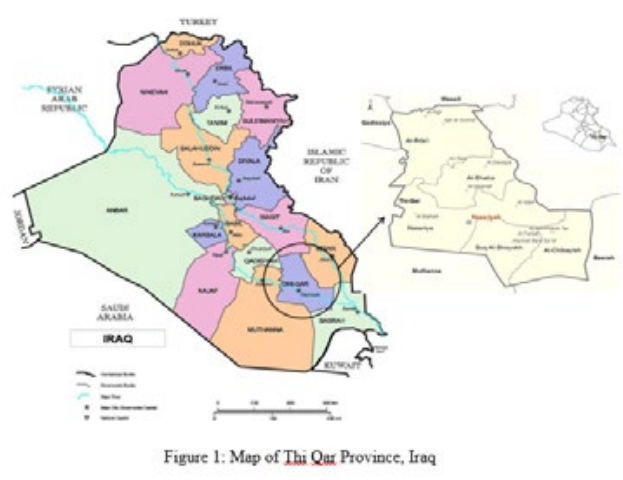

2.2 Conceptual Framework

In this study, the terminology and calculation methodology was adopted from the Water Footprint Assessment Manual, which consists of the global standard for water footprint assessment developed by the Water Footprint Network [13]. The water footprint is an indicator of water use that looks at both direct and indirect water use of a consumer or producer. Direct water use refers to the water use by the consumer or producer itself. Indirect water use refers to the water use in the production chain of products bought by the consumer or producer. The water footprint of a product (good or service) is the volume of fresh water used to produce the product, summed over the various steps of the production chain. 'Water use' is measured in terms of water volumes consumed. In the present study, blue and green water footprints were assessed for cultivating barley. The blue water footprint is defined as the volume of freshwater that evaporated from the global blue water resources (surface water and ground water) by any activities. The green water footprint is the volume of water 
evaporated from the global green water resources (rainwater stored in the soil as soil moisture).

\section{$2.3 \quad$ Data Inventory}

All data pertinent to this study were collected from the Department of Meteorology, Department of Agriculture, Department of Irrigation, reports, books and other sources. A complete inventory database provides information on the consumption of freshwater during the growing stages of barley. CROPWAT 8.0 is a decision support system developed by the Land and Water Development Division of FAO for planning and management of irrigation. CROPWAT 8.0 is a practical tool to calculate the crop water requirements, reference evapotranspiration and crop irrigation requirements as well as the management of irrigation schemes. It allows the recommendations for improving irrigation practices, the planning of irrigation schedules under different water supply conditions and assessing production under rain fed conditions or deficit irrigation (FAO 1992). Calculation of irrigation schedules in CROPWAT 8.0 was done based on the water balance method. Input and output modules of CROPWAT 8.0 are shown in Table 1.

Table 1: Input and output modules of CROPWAT 8.0

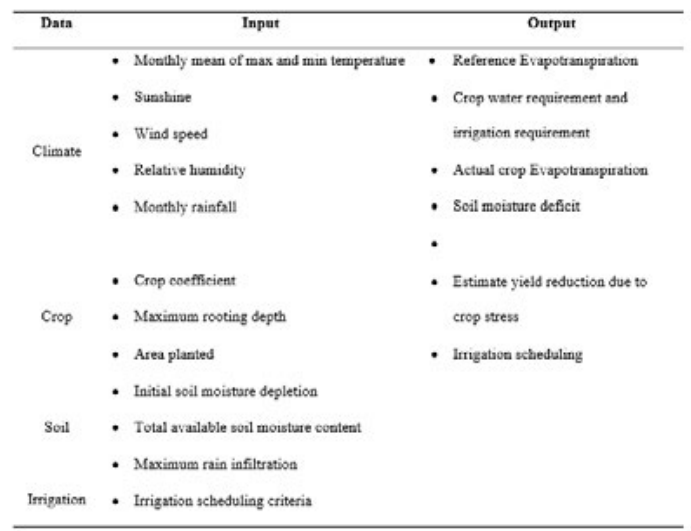

The climatic parameters that are required as inputs in the CROPWAT 8.0 model include elevation, coordinates, precipitation, wind speed, minimum and maximum temperature, relative humidity and sunshine cover. The required data were collected from Thi-Qar Province climate stations provided by the Iraqi Meteorological Institute. The average monthly maximum and minimum air temperatures in degrees Celsius $\left(\mathrm{C}^{\circ}\right)$ are required. The relative humidity is the ratio between the amount of water in the ambient air holds and the amount it could hold at the same temperature was also used as input. As the temperature changes during the day, the relative humidity also changes substantially. The average daily wind speed in metres per second (m/s) measured at $2 \mathrm{~m}$ above the ground level was also required. The height at which wind speed is measured was also considered as wind speeds measured at different heights above the soil surface differ greatly. Daily precipitation data were obtained from climatic stations located in Thi Qar province. In addition, sunshine duration that expresses the cloudiness of the atmosphere was also included in the CROPWAT 8.0 model.

To determine the irrigation requirements of the Thi-Qar Province, information on the various crop characteristics such as length of the growth cycle, crop factors, rooting depth, etc. were collected. A local survey was carried out in the irrigation scheme to assess the crops grown rainfed as well as under irrigation. The present cropping pattern was assessed through field observations, interviews with farmers and additional information from other agencies, for instance the Revenue Department. Crops information collected from the field includes:

Crop and crop variety

First and last planting date

First and last harvesting date

Indicative yield level

Indicative irrigation practices (field irrigation methods, irrigation frequencies and interval, irrigation application depths)

More accurate information was collected from the Agricultural Research Stations on crop characteristics such as length of individual growth stages, crop factors, relating crop evapotranspiration to reference evapotranspiration, rooting depth, allowable depletion levels and yield response factors. Crop co-efficient is the ratio between the actual evapotranspiration of crop (Etc) and the reference crop evapotranspiration. The soil parameters are important for irrigation scheduling and required for irrigation scheduling using the FAO CROPWAT 8.0 model. Soil parameters include Total available soil moisture content, Initial soil moisture depletion, Maximum rooting depth and Maximum rain in filtration rate.

The evapotranspiration rate from a reference surface is called the reference crop evapotranspiration or reference evapotranspiration and is denoted as ETo. ETo is the reference surface and a hypothetical grass reference crop with specific characteristics. The only factors affecting ETo are climatic parameters. The Penman-Monteith method was used for determining ETo (FAO 1998). While, effective rainfall is defined as that part of the rainfall which is effectively used by the crop after rainfall losses due to surface run off and deep percolation have been accounted for. The effective rainfall is the rainfall used to determine the crop irrigation requirements. The efficiency of rainfall will decrease with increasing rainfall. For most rainfall values below $100 \mathrm{~mm} / \mathrm{month}$, the efficiency will be approximately $80 \%$. The assessment of the irrigation potential, based on soil and water resources was done by simultaneously assessing the irrigation water requirements (IWR). Net irrigation water requirement (NIWR) is the quantity of water necessary for crop growth expressed in $\mathrm{m} 3 /$ ha per year. Information on irrigation efficiency was gathered to transform NIWR into grossirrigation water requirement (GIWR), which is the quantity of water to be applied in reality including water losses. Multiplication of GIWR with the area that is suitable for irrigation provides the total water requirement for Thi Qar province.

\subsection{Water Footprint Assessment}

Water footprint analysis was carried out following the Water Footprint Assessment Manual developed by Hoekstra et al (2009). The total water footprint of an agricultural cultivation (WFcrop) is the sum of the blue (WFblue) and green (WFgreen) water footprints and expressed in unit of $\mathrm{m} 3 /$ ton [7]. The blue water footprint refers to the consumptive use of surface and ground water considering blue water evaporation, incorporation and lost return flow. Green water footprint is defined as green water evaporation combining the permanent water embodied in the crop, with the rainwater consumed during plant growth (evapotranspiration from plants and soils). Green water is the precipitation on land that does not run off or recharge the groundwater [9]. The blue and green water footprint were calculated from day one of planting until the day of harvesting with a time span referred to as the total length of growing period (lgp). The blue and green water footprints were calculated by:

\section{『WF 』_(crop,blue ) $=\llbracket C W U \rrbracket \_b l u e / Y$ (m3/ton)} Equation (1)

\section{$\llbracket W F \rrbracket($ crop,green $)=\llbracket C W U \rrbracket \_g r e e n / Y \quad(m 3 /$ ton $)$ Equation (2)}

Where:

CWU $\quad=$ crop water use $\left(\mathrm{m}^{\wedge} 3 / \mathrm{ha}\right)$

$\mathrm{Y} \quad \quad=$ crop yield (ton/ha)

The total water footprint was calculated by summing the blue water footprint and the green water footprint:

\section{$\llbracket \mathrm{WF} \rrbracket_{-}(\mathrm{crop}$, total $)=\llbracket \mathrm{WF} \rrbracket_{-}(\mathrm{crop}, \mathrm{green}) \llbracket+\mathrm{WF} \rrbracket_{-}(\mathrm{crop}, \mathrm{blue})(\mathrm{m} 3 /$ ton $)$ Equation (3)}

\subsection{RESULTS AND DISCUSSION}

\subsection{Climate}

Climate in Iraq is characterized by hot to extreme hot during summer starting from July, June and August and some time to September. Rain season begins in October and ends in May. In the central part of Iraq, the climate is a sub-tropic and it is described by a rainy season starting in October until May in the following year. During the rainy season, the rain could be heavier in October and January. The summer season is dry, hot season and the temperature reaches its highest level starting from July until August. The humidity in the south of Iraq is considered is the highest from 
other parts of the country because it is close to the Persian Gulf Sea which is the air moisture is the greater.

In the study area the average temperature in winter is about 15 ${ }^{\circ} \mathrm{C}$ during the day and in the night it reach $3{ }^{\circ} \mathrm{C}$, sometime remain above freezing. In summer, the temperature can reach it maximum with $46{ }^{\circ} \mathrm{C}$ in July and April. Sunshine in winter is about 5.3 hour per day and during the summer seasons it is about 10.7 hour per day. The wind in Thi-Qar province ranging in winter from $2.1 \mathrm{~m} / \mathrm{s}$ to $5.1 \mathrm{~m} / \mathrm{s}$ in summer. The average rainfall in summer which is rarely observed and during the winter season it may reach to $87.3 \mathrm{~mm}$, except for the few occasion that flood happen. The humidity during the winter is about $80 \%$ and in the summer season it reach it lowest about $15 \%$, due to the nature of dry and hot summer in Thi-Qar Province, Iraq.

Temperature is one of the important elements of climate that has a large effect on the environment and all the organisms that live in it. The changing in temperature has highly affect agriculture sector, which it helps to increase the evaporation rate and may harm crops that cannot endure the high temperature degree. The increasing in temperature will increase the photosynthesis rate and the respiration process; hence it will increase the water demand for these crops during their lifetime. These kinds of effect will also damage the productivity of many staple crops [14].

The temperature for this study was obtained for ten years from 2005 to 2015 . The maximum degree recorded was $46.41^{\circ} \mathrm{C}$ in July and April during the summer season, and the lowest degree recorded was $6.7^{\circ} \mathrm{C}$ in January during winter season. The temperature starts to increase from April until it reach it highest in June and then starts to decrease until it reach it lowest value in January. Winter starts from January from each year and the lowest temperature recorded in that month can reach until $1.3^{\circ} \mathrm{C}$. Summer is the longest season in Iraq starts from May until September with the highest temperature was recorded in June with $46^{\circ} \mathrm{C}$.

Figure 2 shows the average maximum and minimum temperature in Thi-Qar city for duration of 10 years (2005 - 2015). It shows the highest average minimum and maximum temperatures were recorded in June, July and August, whereas the lowest average minimum and maximum temperatures were found in January and December

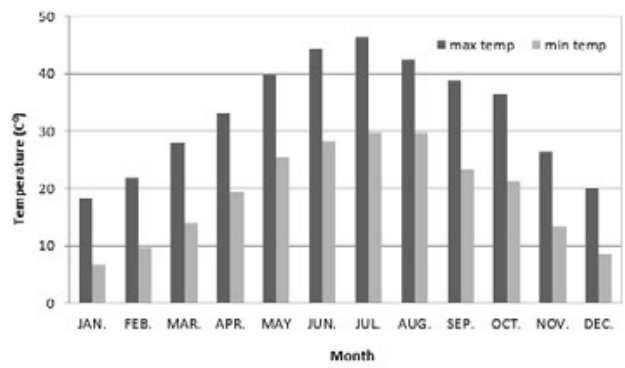

Figure 2: Average of annual maximum and minimum temperature in Thi-Qar

\section{Province.}

Humidity is the amount of the water vapor in the air or the amount of air moisture which the percentage of the total air vapor can hold [18]. Evaporation is greater in summer and at mid-day than in winter and at night. The average of humidity is low in Thi-Qar Province even in winter season. The maximum rate recorded in January was $62.2 \%$, whereas the lowest rate for humidity was in June and July, when the temperature reaches it maximum degree with about $18.9 \%$. Figure 3 shows the lowest average rate $(18.9 \%)$ recorded in June and the highest average rate was during the winter season in February where it reaches up to $53.5 \%$.

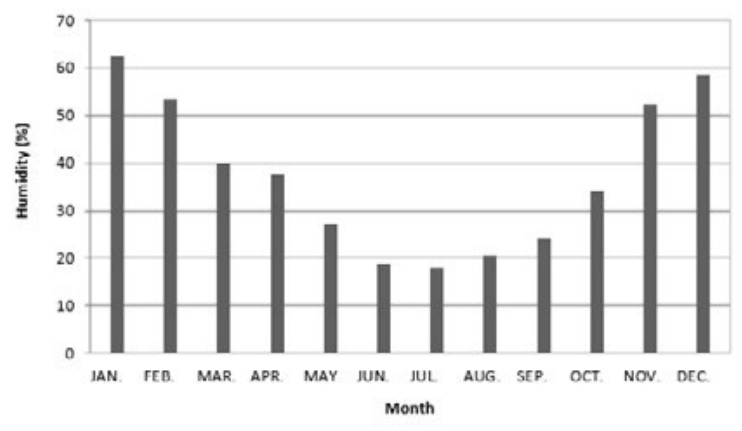

Figure 3: Average of annual humidity in Thi-Qar Province

The rainfall starts from October with only $9.84 \mathrm{~mm}$ and increasing to reach until $22.4 \mathrm{~mm}$ in November (Figure 4). Rainfall continues in the Province of Thi-Qar province until May with $7.24 \mathrm{~mm}$ because of the decrease of the air depressions effectiveness. No rainfall recorded from June to September.

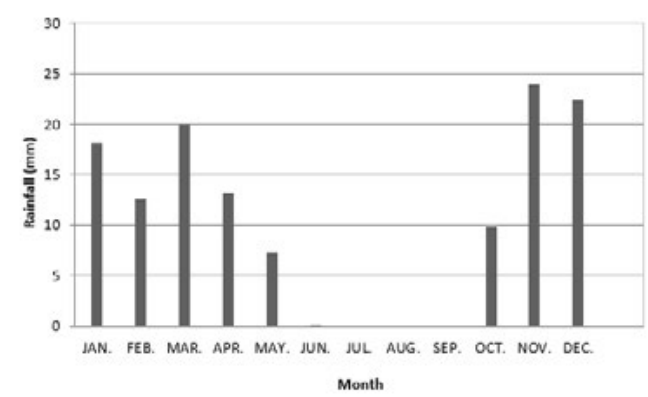

Figure 4. Average annual of rainfall in Thi- Qar Province

Sunshine is the energy emitted from the sun itself and considers as one of the major energy sources on earth [10]. Figure 5 shows the average of sunshine in Thi-Qar Province for 10 years. Thi-Qar Province is located in the sub-tropical belt and generally receives a considerable amount of sunshine. The lowest sunshine rates were found in January and February, with 5.6 hour/day and 5.4 hour/day, respectively. The highest sunshine rate was recorded in July (11.2 hour/day). Sunshine increases from January to July and decreases in August. From November, it decreases till January, which is the month with the lowest sunshine. The sunshine is lower in winter season because the cloud cover and humidity are high compared to summer season.

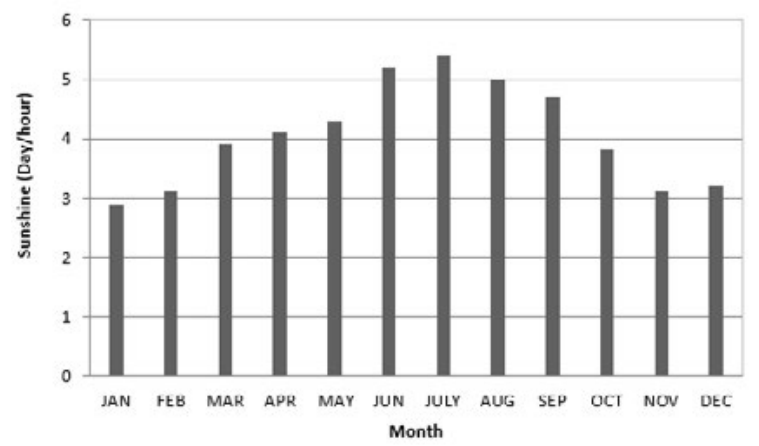

Figure 5: Average annual of sun shine in Thi-Qar Province

Figure 6 shows the average annual wind speeds for 10 years. Wind is an air flowing over the earth surface and forms due to the differences of atmospheric pressure that forces air to flow from zones of higher pressure to zones of lower pressure. The wind patterns are primarily the result of both the pressure of gradient force and the rotation of the earth. Over the course of the year in Thi-Qar Province, wind speeds vary from $2.0 \mathrm{~m} / \mathrm{s}$ to $5.0 \mathrm{~m} / \mathrm{s}$. The highest and lowest average wind speed were recorded with 5.2 $\mathrm{m} / \mathrm{s}$ and $1.9 \mathrm{~m} / \mathrm{s}$, respectively.

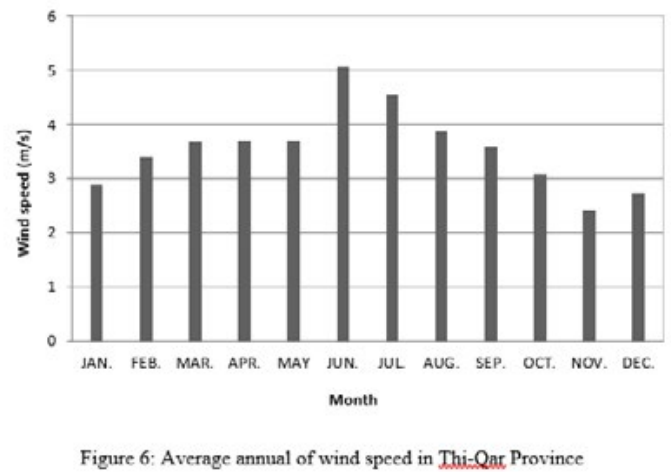

Water Footprint Assessment in Thi-Qar Province

The water footprint method was used in this study for assessing the fresh water consumption for cultivating barley in the Thi-Qar Province. Water footprint assessment includes the blue water footprint and green water footprint by estimating the blue and green water requirements. The blue water footprint refers to the volume of surface and groundwater consumed (evaporates) as a result of growing crop while the green water footprint refers to the rainwater consumed. 
After many years of climate change and dry issues in Thi-Qar Province, this area is now facing many other challenges that are related to the scarcity of fresh water resources. Water footprint is known as an indicator of water scarcity and used to assess the impact of water scarcity and quality of the fresh water resources. Agricultural activity in Thi-Qar Province in winter season focused on barley, while in summer season, vegetables and summer grains crops are planted. Barley is more tolerant to soil salinity. Most barley is used as fodder and commonly harvested before full grain production. The growing season for barley is between October to November. In Iraq, 0.4 - 0.8 million hectares of barley irrigated each year. Barley prefers adequate but not excessive moisture and does poorly in waterlogged soils [6]. The highest total barley production was recorded in 2013 with 2,275 ton/year in ThiQar Province because of the amount of rainfall was higher as compared to other years. The lowest barley production was recorded in 2008 with 166 ton/year because of inadequate precipitation and the low level of Euphrates River that occurred for a few years.

In Iraq, blue water is considered as a critical resource, especially for agriculture activities during dry season. Iraq is a sub-tropical country which has long dry season. Therefore, the blue water footprint is always high due to the high dependent for water resource to irrigate crops in the area. Figure 7 shows that the blue water footprint for barley cultivation recorded in 10 years ranged from $761 \mathrm{~m} 3 /$ ton $-2,275 \mathrm{~m} 3 /$ ton. Whereas the green water footprint for the same years was ranged from $47 \mathrm{~m} 3 /$ ton $-1,235 \mathrm{~m} 3 /$ ton The largest amount of the water footprint in the Thi-Qar Province was recorded for cultivating barley that refers to the water requirement from the planting date of this crop until the harvesting phase.

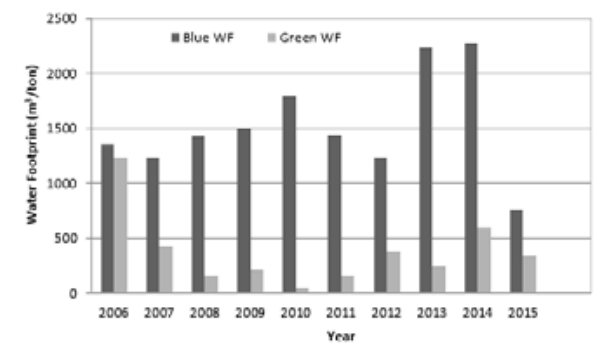

Figure 7: Yearly amount of blue and green water footprint $\left(\mathrm{m}^{3} /\right.$ ton) of barley from 2006 to 2015

Comparing the water consumption of different crops can lead us to a better understanding on different water consumption required for growing crops. Barley cultivation recorded high blue water consumption in Thi-Qar Province due to the growing period in summer with high temperature and no precipitation implying that the main water source is from the blue water including surface and groundwater. Previous studies have been done to assess water footprint for growing a number of crops in Kurdistan Province, the northern part of Iraq. Their results show that the green water footprint is higher than blue water footprint, while the present study showed the different results. This is due to the higher precipitation rate received in Kurdistan province compared to Thi-Qar province.

Green water footprint refers to the volume of rainwater consumed during the production process. The volume of water taken up by plants from the soil insofar it concerns soil water originating from infiltrated rainwater [5]. The agriculture sector mainly depends on irrigation water than rain water especially in the middle region. In addition, the geographic location of the middle part is dry area which is characterized by water scarcity and low annual rainfall [19]. The precipitation can help crop productivity by providing water. Thi-Qar Province is a tropical area and the rain is rare particularly in summer could influence the crops to successfully grow in that time. Therefore, the main source for agriculture is the surface water in irrigation system for Thi-Qar Province.

The high water footprint implying that the area may suffer from water inefficient agricultural practice. The construction of dams is an urgent need to investigate and regulate water for irrigation during summer and winter seasons as well as the water productivity in agriculture can be improved for instance by applying advanced techniques of rainwater harvesting and developing an irrigation network system to guarantee sufficient water. In addition, farmer's skills need to be improved and enhanced to enable them using these systems, locating more investment fund to replacement old network of water installation by modern one and development of agriculture products. This study has the potential to motivate business industries in the food and beverage sectors to improve their supply chain to use less water in their production processes. It is also aims to develop the concept of water footprint as a market driver instrument that would motivate businesses in the food and beverage sector to minimize water consumption throughout their supply chain in Iraq.

\subsection{LIMITATION AND RECOMMENDATION FOR FUTURE STUDY}

In this study, several assumptions and exclusions were made for inventory data, especially the data for the assessment of grey water footprint for barley. Data constraints are the main factor contributing to the successful of the holistic assessment of water footprint for growing crops in Thi-Qar Province. Finally, some recommendations for future study were suggested as following:

i. The allocation and consumption of water for environmental purposes shall be recognized and given appropriate considerations based on the best scientific information available considering the spatial and temporal water requirements.

ii. Water is a common use resource and the water allocation system shall distinguish and separate water use permit from land title.

iii. All stakeholders should play roles towards sustainable water management in Thi Qar province.

iv. Application of water footprint assessment method to estimate water consumption for other staple crops to obtain a full picture about the information of water availability and water scarcity in in Thi-Qar Province in order to improve irrigation system and to maximize the yield of crop production.

\subsection{CONCLUSION}

The water footprint method that used in this study was considered as a holistic environmental tool to understand the issue related to freshwater resources and what changes are needed to improve the sustainability, efficiency and equitability of water use. The demand for water increases particularly by the agriculture sector with the increasing population size and urban area in Thi-Qar Province. This issue needs an urgent initiative to develop a sustainable water management in order to maintain the limited water resources.

The challenge is to reduce the water consumption without affecting the demands thus reducing the water footprint per unit of crop. The high value of total water footprint depends on the total production of the crop per cultivated area (in ha). The results show that the blue water footprint is higher than green water footprint in Thi-Qar Province. Furthermore, green water footprint depends on the amount of the rainfall throughout the year, however, Thi-Qar Province received low amount of rainfall. The blue water footprint depends on the contribution of water relies on irrigation, which is represented the Euphrates River in Thi-Qar as a main source of freshwater. Thi-Qar Province is considered as dry province while the Northern provinces receiving a higher amount of precipitation than Thi-Qar province, the Southern of Iraq. In the present study, the water footprint has a larger component of blue water, implying that the Province relies on applied surface water (primarily in irrigation). Furthermore, there are huge variations of the water footprint or crop water requirement from crops grown in different Provinces of Iraq due to climate and geographical conditions. For example, the cultivation of main crops in North of Iraq depend on precipitation as a main source for the requirements to the growth of these crops because of the amount of rainfall is considered higher in North of Iraq compared to the Thi-Qar Province and other provinces located in the Southern of part of Iraq, which depending on the irrigated system. Thi-Qar Province received rainfall below than $100 \mathrm{~mm}$ per year. The climate change in the dry land and semi-arid and sub-humid causes high annual evaporation rates due to high temperatures and their impact on other elements of the climate such as wind speed and solar radiation in excess of the total annual evaporation in the Thi-Qar province.

The results of this study are very important for Iraqi Government towards sustainable water management for agricultural sector in Iraq, particularly in Thi-Qar Province. It can also provide guideline for the best management practise for growing crops in this province.

\section{References}

[1] Alaskari, O., M. Ahmad, N. Dhafr \& R. Pinedo-Cuenca 2013. Critical successful factors (CSFs) for successful implementation of lean tools and ERP systems.

[2] Aldaya, M. M., A. K. Chapagain, A. Y. Hoekstra \& M. M. Mekonnen. 2012. 
The water footprint assessment manual: Setting the global standard Ed.: Routledge.

[3] Allen, R., W. Pruitt, J. Businger, L. Fritschen, M. Jensen \& F. Quinn 1996. Chapter 4 "Evaporation and Transpiration" in ASCE Handbook of Hydrology. New York, NY: 125-252.

[4] Allen, R. G., L. S. Pereira, D. Raes \& M. Smith 1998. Crop evapotranspirationGuidelines for computing crop water requirements-FAO Irrigation and drainage paper 56. FAO, Rome 300(9): D05109.

[5] Chapagain, A. \& A. Hoekstra 2008. Globalization of Water: Sharing the Planet's Freshwater Resources, Blackwell Publishing, Oxford, UK.

[6] Clark, L. J., A. H. Price, K. A. Steele \& W. R. Whalley 2008. Evidence from near-isogenic lines that root penetration increases with root diameter and bending stiffness in rice. Functional Plant Biology 35(11): 1163-1171.

[7] Ercin, A., M. Aldaya \& A. Hoekstra 2009. A pilot in corporate water footprint accounting and impact assessment: the water footprint of a sugarcontaining carbonated beverage.

[8] Hiniker, M. 1999. Sustainable solutions to water conflicts in the Jordan Valley. Cambridge Review of International Affairs 12(2): 255-273.

[9] Hoekstra, A. Y. 2009. Human appropriation of natural capital: A comparison of ecological footprint and water footprint analysis. Ecological Economics 68(7): 1963-1974.

[10] Jones, G. G. \& L. Bouamane 2012. “ Power from Sunshine”: A Business History of Solar Energy.

[11] Ma, J., A. Y. Hoekstra, H. Wang, A. K. Chapagain \& D. Wang 2006. Virtual versus real water transfers within China. Philosophical Transactions of the Royal Society B: Biological Sciences 361(1469): 835-842.

[12] Macdonald, H. 2002. Geopolitics and Middle East Conflict.

[13] Mekonnen, M. M. \& A. Y. Hoekstra 2011. National water footprint accounts: the green, blue and grey water footprint of production and consumption.

[14] Mittler, R., A. Finka \& P. Goloubinoff 2012. How do plants feel the heat? Trends in biochemical sciences 37(3): 118-125.

[15] Peter, H. G., H. Cooley, M. Cohen, M. Morikawa, J. Morrison \& M. Palaniappan 2008. The World's Water 2008-2009: The Biennial Report on Freshwater Resources, Oakland, CA: Island Press.

[16] Priscoli, J. D. \& A. T. Wolf. 2009. Managing and transforming water conflicts Ed.: Cambridge University Press.

[17] Sadik, A. \& S. Barghouti 1994. The water problems of the Arab world: Management of scarce water resources. Water in the Arab World, Harvard University Press, Cambridge: 4-37.

[18] Umoh, V. A., A. Otu, H. Okpa \& E. Effa 2013. The Pattern of Respiratory Disease Morbidity and Mortality in a Tertiary Hospital in Southern-Eastern Nigeria. Pulmonary medicine 2013.

[19] Zakaria, S., N. Al-Ansari, M. Ezz-Aldeen \& S. Knutsson 2012. Rain water harvesting at eastern Sinjar Mountain, Iraq. Geoscience Research 3(2): 100. 